\title{
Bullous Pemphigoid-like Skin Eruption during Treatment with Rivaroxaban: A Clinical Case Study
}

\author{
Cristiana Ferreira ${ }^{1}$, Ana Oliveira ${ }^{2}$, Antonia Furtado ${ }^{3}$, Natividade Rocha ${ }^{2}$, José Almeida Ribeiro ${ }^{3}$ \\ ${ }^{1}$ Serviço de Imunoalergologia, Centro Hospitalar Vila Nova de Gaia/Espinho, Portugal \\ ${ }^{2}$ Serviço de Dermatologia, Centro Hospitalar Vila Nova de Gaia/Espinho, Portugal \\ ${ }^{3}$ Serviço de Anatomia Patológica, Centro Hospitalar Vila Nova de Gaia/Espinho, Portugal \\ ${ }^{4}$ Serviço de Medicina Interna, Centro Hospitalar Vila Nova de Gaia/Espinho, Portugal
}

Received: $15 / 08 / 2017$

Accepted: $28 / 11 / 2017$

Published: $15 / 01 / 2018$

How to cite this article: Ferreira C, Oliveira A, Furtado A, Rocha A, Ribeiro J. Bullous pemphigoid-like skin eruption during treatment with rivaroxaban: a clinical case study. EJCRIM 2018;5: doi:10.12890/2018_000724.

Conflicts of Interests: The Authors declare that there are no competing interests.

This article is licensed under a Commons Attribution Non-Commercial 4.0 License

\section{ABSTRACT}

Little has been documented about hypersensitivity reactions caused by treatment with rivaroxaban. This paper reports a bullous pemphigoid-like skin eruption that occurred in a 76-year-old female patient during rivaroxaban treatment. This case highlights the vigilance required by healthcare workers in recognising potential adverse effects of newly marketed drugs and in making medication changes when necessary. A bullous pemphigoid-like eruption due to treatment with rivaroxaban has not, to the best of the Authors' knowledge, been reported previously in the literature.

\section{LEARNING POINTS}

- Rivaroxaban can cause a bullous eruption apparently similar to epithelial toxic necrolysis (or to Stevens-Johnson syndrome).

- There is an apparent similarity between skin adverse events caused by the different anticoagulants.

- The anticoagulant responsible for the skin side-effects can be identified on clinical grounds by the correct differential diagnosis.

\section{KEYWORDS}

Rivaroxaban, bullous pemphigoid-like, cutaneous drug eruptions

\section{INTRODUCTION}

Cutaneous drug eruptions are among the most common adverse drug reactions and may often represent a challenging diagnostic problem. While a single drug can elicit a range of reaction patterns, no reaction pattern is specific to a particular drug. Although the temporal link between initiation of drug therapy and the onset of a drug rash is critical for the diagnosis, drug reactions may also occur during chronic drug administration.

Blisters are a well-known manifestation of cutaneous reactions to drugs. In many types of drug reactions, bullae and vesicles may be found in addition to other manifestations. Bullae are usually noted in erythema multiforme, Stevens-Johnson syndrome, toxic epidermal necrolysis, urticaria, vasculitis, porphyria cutanea tarda, and phototoxic reactions ${ }^{[1]}$. Although drug-induced bullous pemphigoid eruptions are rare, they can be caused by certain drugs, such as furosemide, heparin, ibuprofen, captopril, and many others ${ }^{[2-6]}$. 
Rivaroxaban (Xarelto ${ }^{\circledR}$, Bayer Corporation, Pittsburgh, PA) is a new oral anticoagulant drug. It acts as a direct factor Xa inhibitor and is used in venous thromboembolism prophylaxis. This drug is increasingly prescribed because, as an oral drug, it is easily handled during therapy; moreover, no coagulation monitoring is needed, and it has a wide therapeutic index. However, phase III studies have listed hypersensitivity to rivaroxaban as 'undetermined' $\left.{ }^{\prime}\right]$.

\section{CASE DESCRIPTION}

A 76-year-old female patient with a medical history of paroxysmal atrial fibrillation and depression was hospitalised on 10 January 2016 due to a pulmonary thromboembolism. During hospitalisation, the patient started sertraline 100 mg daily, rivaroxaban 20 mg daily, and furosemide $10 \mathrm{mg}$ twice daily. Fifteen days after the start of therapy, the patient developed a rash characterised by urticarial plaques on her back, upper limbs, and anterior surfaces of her thighs. In addition, tense, sero-haemorrhagic blisters developed on both legs (Figs. 1 and 2). No lesions were observed on mucosae.

The patient was followed in the Internal Medicine and Dermatology Service. The tentative diagnosis was that of a bullous pemphigoid secondary to drug use or neoplastic aetiology. Given the known association between furosemide and bullous pemphigoid, its use was discontinued and the patient started on therapy using a topical corticosteroid, betamethasone cream, twice a day.

The results on the patient's diagnostic exams were as follows: a WBC of 7220 with $14.4 \%$ eosinophils, platelets 197,000/ $\mu$ l, and ESR 60 mm/ hr. The CEA, Ca 15-3, Ca 19-9, and Ca 125 results were within normal ranges. The search for anti-skin, anti-basement, epidermal membrane and anti-keratinocyte autoantibodies (indirect immunofluorescence [IIF] in peripheral blood) was negative. Histological examination disclosed intraepidermal blistering with eosinophils and apoptotic keratinocytes inside, with significant spongiosis in the neighbouring epidermis (Fig. 3). Discrete infiltrates of eosinophils were diffusely represented among spongiotic areas and throughout the upper part of the dermis in a perivascular and interstitial infiltrate pattern (Fig. 4). Immunofluorescence was negative for IgA, IgG, IgM, C3, and C1q.

Two weeks after the use of furosemide had been discontinued, the cutaneous condition worsened; bullous lesions now appeared on the forearms (Fig. 5). At that time, rivaroxaban was discontinued and replaced with warfarin, while furosemide was reintroduced. A rapid improvement in the lesions was noted within 1 week, and no relapse occurred during the 12-month follow-up.

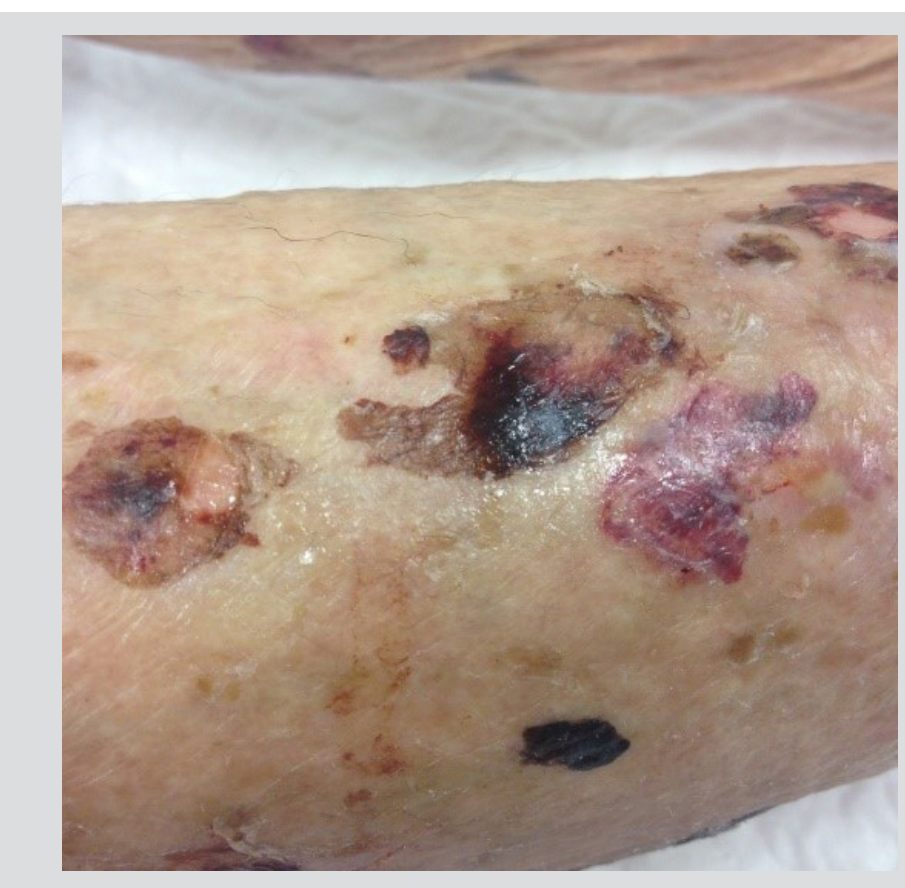

Figure 1. Bullous pemphigoid-like skin eruption on the legs

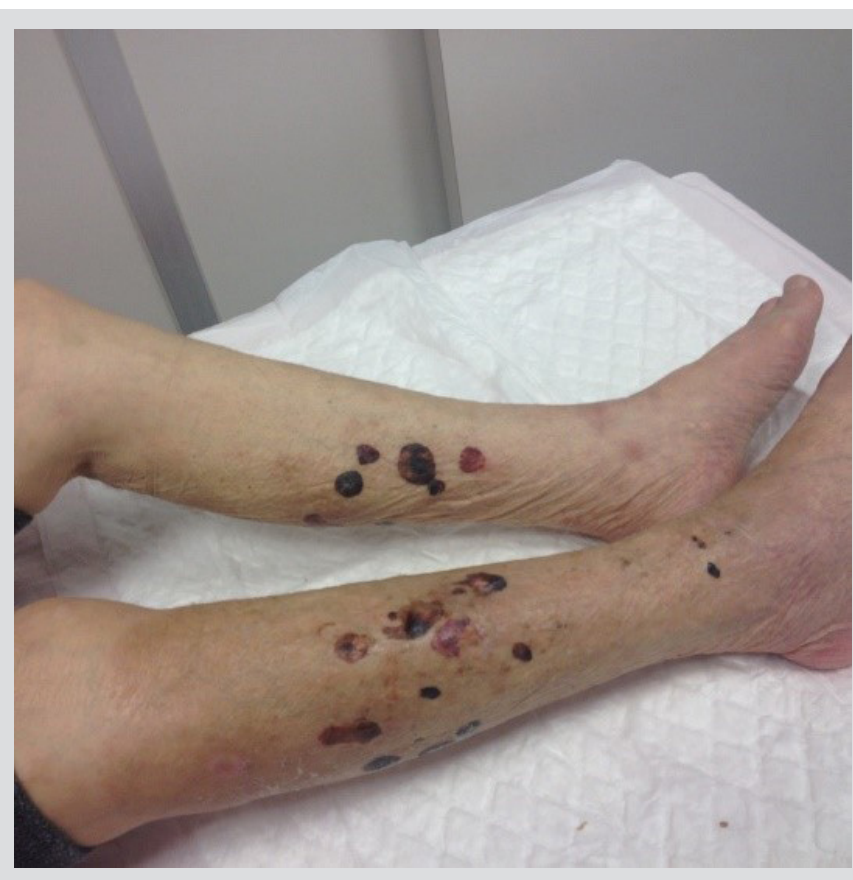

Figure 2. Bullous pemphigoid-like skin eruption on the legs 


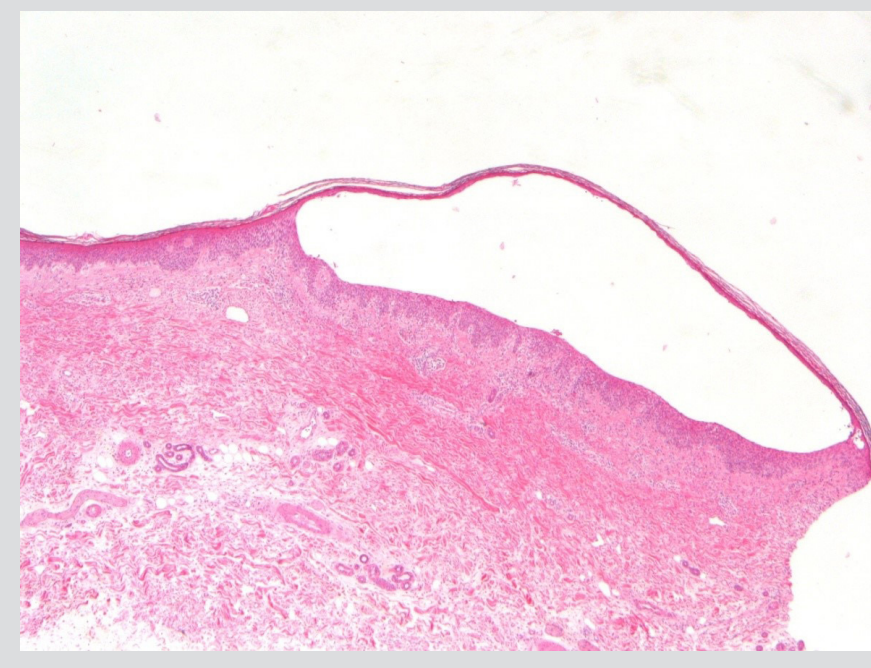

Figure 3. Histological examination using H\&E staining and low power magnification revealed intraepidermal blistering
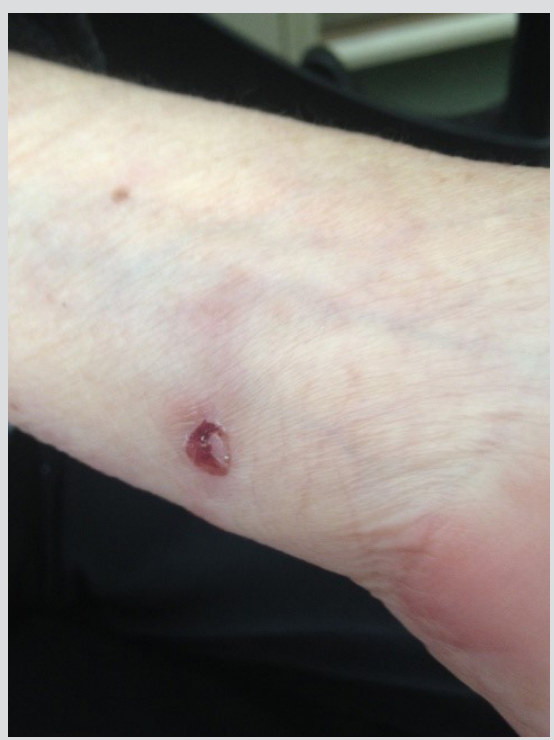

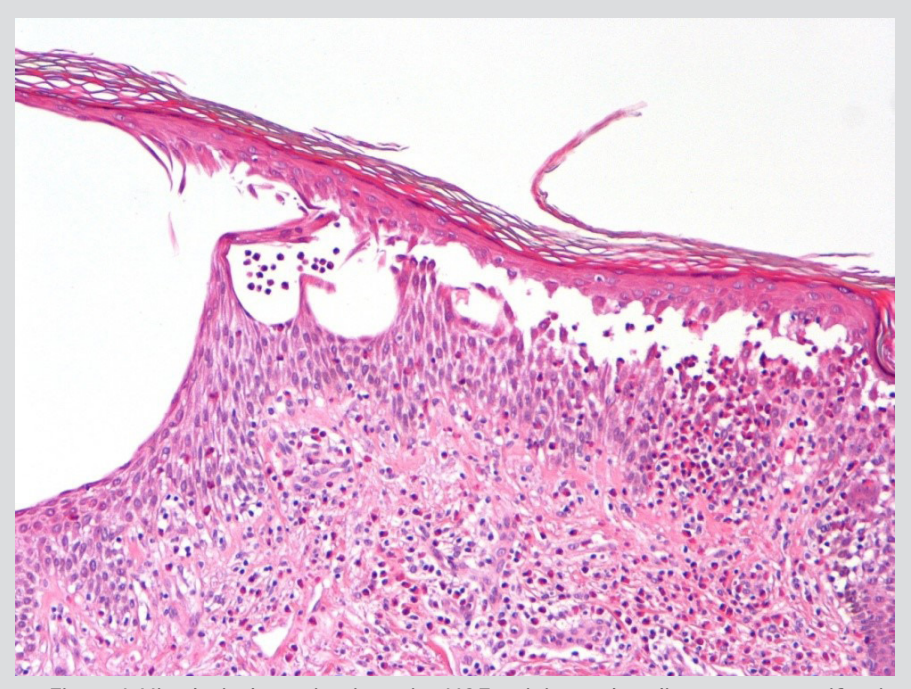

Figure 4. Histological examination using H\&E staining and medium power magnification revealed eosinophils in tiny collections that were abundantly present among spongiotic areas in the epidermis (arrow) and throughout the upper part of the dermis (arrowhead)

Figure 5. Bullous pemphigoid-like skin eruption on forearm

\section{DISCUSSION}

The diagnosis of bullous pemphigoid-like skin eruption due to rivaroxaban was established. Our differential diagnoses included haemorrhagic toxic necrolysis / heparin-induced thrombocytopenia and Stevens-Johnson syndrome (Table 1). However, the patient's normal platelet count, negative Nikolsky's sign, results on the direct immunofluorescence test, bullous eruption in the dermis-epidermis junction, and histologic findings ruled out these diagnoses. Histologically, drug-induced variants of bullous pemphigoid are similar to the typical form and are characteristically composed of eosinophil-rich subepidermal blisters ${ }^{[8]}$. In the initial stage, only eosinophilic spongiosis and numerous dermal eosinophils are present, with eosinophils lining up along the basement membrane ${ }^{[9]}$. At later stages, the blisters may appear to be intraepidermal as a result of keratinocyte regeneration. In the present case, these various morphological features were present and, in a concordant clinical context, were diagnostic for the disease. Negative immunofluorescence studies, as in this case, occur in $4 \%$ of the patients with bullous pemphigoid ${ }^{[1,8]}$.

Cutaneous reactions have been reported during anticoagulant therapy with coumarin derivatives and with unfractionated and lowmolecular-weight heparins and heparinoids ${ }^{[10-12]}$. However, very few data regarding hypersensitivity reactions to rivaroxaban are available; 
we were only able to find two such cases in the literature ${ }^{[13,14]}$. Even though heparins, warfarin, and rivaroxaban have very different mechanisms of action, the clinical similarity of their epithelial side-effects is remarkable. In spite of this similarity, a differential diagnosis between the offending agents can be made with high confidence (Table 2).

\begin{tabular}{|c|c|c|c|c|c|}
\hline & $\begin{array}{c}\text { Steven-Johnson syndrome } \\
\text { (SJS) }\end{array}$ & \multicolumn{2}{|c|}{ Bullous pemphigoid } & \multicolumn{2}{|c|}{ Haemorragic skin eruptions } \\
\hline & & Idiopathic & Drug-induced & $\begin{array}{l}\text { Heparin-induced } \\
\text { skin necrosis }\end{array}$ & $\begin{array}{l}\text { Coumarin-induced } \\
\text { skin necrosis }\end{array}$ \\
\hline $\begin{array}{l}\text { Clinical } \\
\text { features }\end{array}$ & $\begin{array}{l}\text { Rusty macules with } \\
\text { or without epidermal } \\
\text { detachment (<10\% BSA) } \\
\text { Atypical target lesions } \\
\text { (papular lesions with two } \\
\text { zones of colour changes, } \\
\text { with papular, vesicular or } \\
\text { flaccid bullous centre) }\end{array}$ & \multicolumn{2}{|c|}{$\begin{array}{l}\text { - Multiple tense bullae arising on normal or } \\
\text { - } \quad \text { Bullaemathous skin } \\
\text { haemorragic crusts } \\
\text { - } \quad \text { Urticarial papules and plaques, along with bullae } \\
\text { containing serous fluid } \\
\text { - } \quad \begin{array}{l}\text { Pruritus and nonspecific eczematous lesions can } \\
\text { precede }\end{array} \\
\text { - At least } 50 \% \text { of patients have peripheral } \\
\text { eosinophilia }\end{array}$} & $\begin{array}{l}\text { Often associated } \\
\text { with heparin-induced } \\
\text { thrombocytopenia } \\
\text { with thrombosis } \\
\text { Necrosis starts with a } \\
\text { small, erythematous } \\
\text { and painful lesion that } \\
\text { later extends to areas } \\
\text { of necrosis }\end{array}$ & $\begin{array}{l}\text { Pain, oedema and small } \\
\text { subcutaneous } \\
\text { haematoma, followed } \\
\text { by erythematous or } \\
\text { haemorrhagic changes in } \\
\text { demarcated lesions that } \\
\text { become bullous and can } \\
\text { progress to gangrenous } \\
\text { necrosis }\end{array}$ \\
\hline $\begin{array}{c}\text { Mucosal } \\
\text { involvement }\end{array}$ & Severe & Rare & No & & \\
\hline Distribution & Face, neck, trunk & \multicolumn{2}{|c|}{ Lower abdomen, thighs, forearms, legs } & $\begin{array}{l}\text { Injection site, but can also be } \\
\text { generalised }\end{array}$ & $\begin{array}{l}\text { Subcutaneous fatty tissue, eg } \\
\text { breasts, thighs, abdomen } \\
\text { and buttocks }\end{array}$ \\
\hline $\begin{array}{l}\text { Histological } \\
\text { findings }\end{array}$ & $\begin{array}{l}\text { - Subepidermal blister } \\
\text { with overlyng confluent } \\
\text { necrosis of the entire } \\
\text { epidermis; keratinocyte } \\
\text { apoptosis is a hallmark of } \\
\text { SJS } \\
\text { - Sparse perivascular } \\
\text { infiltrate composed } \\
\text { primarily of lymphocytes }\end{array}$ & $\begin{array}{l}\text { - } \quad \text { Subepidermal bullae } \\
\text { Infiltrate composed } \\
\text { of neutrophils and } \\
\text { eosinophils in the } \\
\text { dermis and bulla } \\
\text { cavity }\end{array}$ & $\begin{array}{c}\text { Subepidermal bulla or } \\
\text { intraepidermic }\end{array}$ & $\begin{array}{l}\text { Microvascular thrombi } \\
\text { in small vessels with } \\
\text { minimal inflammation }\end{array}$ & $\begin{array}{l}\text { Areas with thrombosis, } \\
\text { microvascular injury } \\
\text { and fibrin deposits in the } \\
\text { postcapillary veins and } \\
\text { small vessels }\end{array}$ \\
\hline $\begin{array}{c}\text { Presence } \\
\text { of } \\
\text { autoantibodies }\end{array}$ & Negative & $\begin{array}{l}\text { DIF with IgG and/or } \\
\text { C3 in the basement } \\
\text { membrane zone } \\
\text { - IIF (+) in } 70 \% \text { of } \\
\text { patients }\end{array}$ & $\begin{array}{c}\text { DIF and IIF can be } \\
\text { negative }\end{array}$ & $\begin{array}{l}\text { Antibodies against heparin } \\
\text { platelet factor- } 4 \\
\text { complexes }\end{array}$ & \\
\hline Others & $\begin{array}{l}\text { - Systemic symptoms are } \\
\text { usually present (fever, } \\
\text { hepatitis, cytopenias) } \\
\text { - } \quad \text { Progression to toxic } \\
\text { epidermal necrolysis is } \\
\text { possible } \\
\text { - Nikolsky (+/-) }\end{array}$ & Nikolsky (-) & & $\begin{array}{l}\text { Platelet count drops by } 50 \% \\
\text { compared with the } \\
\text { baseline value within } \\
\text { first } 10-14 \text { days of } \\
\text { treatment }\end{array}$ & $\begin{array}{l}\text { - } 10 \text { days after the onset of } \\
\text { therapy } \\
\text { Protein Cor protein S } \\
\text { deficiencies }\end{array}$ \\
\hline
\end{tabular}




\begin{tabular}{|c|c|c|}
\hline Substance group according to site of action & Chemical name & Bullous skin reaction \\
\hline Vitamin $K$ antagonists & Coumarins & $\begin{array}{l}\text { - Haemorrhagic bullous eruption } \\
\text { - } \quad \text { Skin necrosis }\end{array}$ \\
\hline Antithrombin-III activators (heparins) & Glycosaminoglycans & $\begin{array}{l}\text { - Haemorrhagic bullous eruption } \\
\text { - } \quad \text { Bullous-like eruption } \\
\text { - Stevens-Johnson syndrome / Toxic epidermal } \\
\text { necrolysis } \\
\text { - } \quad \text { Bulbous pemphigoid } \\
\text { - Skin necrosis }\end{array}$ \\
\hline Direct factor Xa inhibitors & Xabans & Toxic skin eruption \\
\hline
\end{tabular}

Table 2. Bullous skin reactions to various substance groups with anticoagulant effects

\section{REFERENCES}

1. Goldsmith LA, Katz SI, Gilchrest BA, Paller AS, Leffell DJ, Wolff K. Fitzpatrick's dermatology in general medicine, 8th ed. New York: McGraw-Hill, 2012.

2. Lee A, Thomson J. Drug-induced skin reactions. In: Lee A, ed. Adverse drug reactions. 2nd ed. London: Pharmaceutical Press, 2006, pp. $125-56$.

3. Ma HJ, Hu R, Jia CY, Yang Y, Song LJ. Case of drug-induced bullous pemphigoid by levofloxacin. J Dermatol 2012;39:1086-87.

4. Miguel-Gomez L, Fonda-Pascual P, Carrillo-Gijon R, Muñoz-Zato E. Bullous hemorrhagic dermatosis probably associated with enoxaparin. Indian J Dermatol Venereol Leprol 2016:82:319-20.

5. Perry A, Sparling JD, Pennington M. Bullous pemphigoid following therapy with an oral beta-blocker. J Drugs Dermatol 2005;4:746-48.

6. Gupta S, Alam K, Palaian S, Singh M, Dwari B, Prabhu S, et al. Metronidazole induced bullous fixed drug eruptions: a case report and a review of literature. Internet J Derm 2006;5:1-6.

7. Bayer HealthCare AG. Xarelto (rivaroxaban): Summary of product characteristics as approved by the European Commission, 2011. Available from: http://www.ema.europa.eu/ docs/en GB/document library/EPAR - Product Information/human/000944/WC500057108.pdf

8. Calonje JE, Brenn T, Lazar A, McKee PH. McKee's pathology of the skin. 4th ed. Philadelphia: Elsevier Saunders, 2012

9. Weedon D, Strutton G, Rubin Al. Weedon's skin pathology. 3rd ed. Edinburgh: Churchill Livingstone/Elsevier, 2010.

10. Maldonado Cid P, Alonso de Celada RM, Noguera Morel L, Feito-Rodríguez M, Gómez-Fernández C, Herranz Pinto P. Cutaneous adverse events associated with heparin. Clin Exp Dermatol 2012;37:707-11.

11. Scherer K, Tsakiris DA, Bircher AJ. Hypersensitivity reactions to anticoagulant drugs. Curr Pharm Des 2008:14:2863-73.

12. Bircher AJ, Harr T, Hohenstein L, Tsakiris D. Hypersensitivity reactions to anticoagulant drugs: diagnosis and management options. Allergy 2006;61:1432-40.

13. Vernon HM, Nielsen AK, O'Bryan EC. Hypersensitivity reaction after administration of rivaroxaban (Xarelto). Am J Emerg Med 2016;34:1325.e1-2.

14. Yates J, Choudry M, Keys G. A case report describing a suspected rivaroxaban hypersensitivity reaction in a surgical patient. J Clin Pharm Ther 2013;38:159-61. 